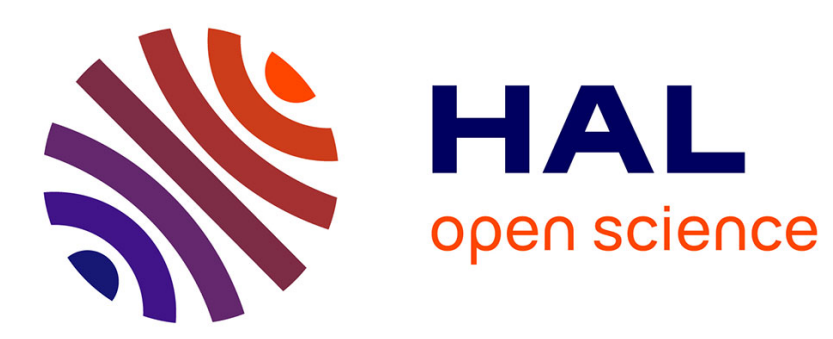

\title{
Late Miocene threshold response of marine algae to carbon dioxide limitation
}

\author{
Clara Bolton, Heather M. Stoll
}

\section{To cite this version:}

Clara Bolton, Heather M. Stoll. Late Miocene threshold response of marine algae to carbon dioxide limitation. Nature, 2013, 500 (7464), pp.558 - 562. 10.1038/nature12448 . hal-01667995

\section{HAL Id: hal-01667995 \\ https://hal.science/hal-01667995}

Submitted on 19 Oct 2021

HAL is a multi-disciplinary open access archive for the deposit and dissemination of scientific research documents, whether they are published or not. The documents may come from teaching and research institutions in France or abroad, or from public or private research centers.
L'archive ouverte pluridisciplinaire HAL, est destinée au dépôt et à la diffusion de documents scientifiques de niveau recherche, publiés ou non, émanant des établissements d'enseignement et de recherche français ou étrangers, des laboratoires publics ou privés. 
1 Late Miocene threshold response of marine algae to carbon dioxide limitation

2

3 Clara T. Bolton and Heather M. Stoll

4

5 Geology Department, University of Oviedo, Jesus Arias de Velasco S/N, 33005,

6 Oviedo, Asturias, Spain

8 Coccolithophores are marine algae that use carbon for calcification and

9 photosynthesis. The long term adaptation of these and other marine algae to

10 decreasing carbon dioxide levels during the Cenozoic era ${ }^{1}$ has resulted in modern

11 algae capable of actively enhancing carbon dioxide at the site of photosynthesis.

12 This enhancement occurs through the transport of dissolved bicarbonate $\left(\mathrm{HCO}_{3}{ }^{-}\right)$

13 and with the help of enzymes whose expression can be modulated by variable

14 aqueous carbon dioxide concentration, $\left[\mathrm{CO}_{2}\right]$, in laboratory cultures ${ }^{2,3}$.

15 Coccolithophores preserve the geological history of this adaptation because the

16 stable carbon and oxygen isotopic compositions of their calcite plates (coccoliths),

17 which are preserved in the fossil record, are sensitive to active carbon uptake and transport by the cell. Here we use a model of cellular carbon fluxes and show that

19 at low $\left[\mathrm{CO}_{2}\right]$, the increased demand for $\mathrm{HCO}_{3}{ }^{-}$at the site of photosynthesis results in a diminished allocation of $\mathrm{HCO}_{3}{ }^{-}$to calcification, which is most pronounced in

21 larger cells. This results in a large divergence between the carbon isotopic compositions of small versus large coccoliths only at low $\left[\mathrm{CO}_{2}\right]$. Our evaluation of

23 the oxygen and carbon isotope record of size-separated fossil coccoliths reveals

24 that this isotopic divergence first arose during the late Miocene to the earliest 
response of the cells' carbon acquisition strategies to decreasing $\left[\mathrm{CO}_{2}\right]$. The

documented coccolithophore response is synchronous with a global shift in terrestrial vegetation distribution between 8 and 5 Myr ago, which has been interpreted by some studies as a floral response to decreasing partial pressures of carbon dioxide $\left(\mathrm{CCO}_{2}\right)$ in the atmosphere ${ }^{4-6}$. We infer a global decrease in carbon dioxide levels for this time interval that has not yet been identified in the sparse $p \mathrm{CO}_{2}$ proxy record ${ }^{7}$ but that is synchronous with global cooling and progressive glaciations $^{8,9}$.

Coccolithophores are unique among algae in that they use carbon both for calcification and for photosynthesis. Cultures of coccolithophores grown under ambient, $\mathrm{CO}_{2^{-}}$ limiting conditions show an unusually large array (up to $5 \%$ ) of non-equilibrium carbon and oxygen stable isotopic fractionations $\left(\delta^{13} \mathrm{C} \text { and } \delta^{18} \mathrm{O}\right)^{10,11}$. These isotope 'vital effects', so-called because they are thought to result from biological processes, are also evident in coccoliths from recent sediments and sediment traps. The isotopic difference between small and large coccoliths diminishes in cultures grown at elevated $\left[\mathrm{CO}_{2}\right]$ (increased dissolved inorganic carbon concentration at constant $\left.\mathrm{pH}\right)^{12}$ (Fig. 1b) and is absent in fossil coccoliths from past Palaeocene greenhouse climates ${ }^{13,14}$. We assert that vital effects reflect the adaptation of cellular carbon fluxes to aqueous $\mathrm{CO}_{2}$ availability, and in a new model we reveal the origin of carbon isotope vital effects. We then evaluate the timing of the emergence of vital effects in the fossil record and its relationship to Cenozoic climate evolution and the long-term decrease in $p \mathrm{CO}_{2}$.

Photosynthesis in large cells may be more sensitive to limitation by diffusive $\mathrm{CO}_{2}$ supply because of the lower ratio of surface area to volume (Supplementary Fig. 2). 
51 Active transport of $\mathrm{HCO}_{3}{ }^{-}$for photosynthesis is expected to be driven by the extent of

52 diffusive $\mathrm{CO}_{2}$ limitation, and may therefore differ between small and large cells. A new model (Supplementary Discussion) reveals the active $\mathrm{HCO}_{3}{ }^{-}$fluxes to the cell, the site of photosynthesis (chloroplast) and the site of calcification (coccolith vesicle, CV) required to explain the observed array of carbon isotopic fractionation into organic matter and coccolith calcite, $\varepsilon_{\mathrm{p}}$ and $\varepsilon_{\text {coccolith }}$ respectively, observed in coccolithophore species of different sizes grown in culture at variable $\left[\mathrm{CO}_{2}\right]^{12,15}$ (Fig. 1). The model confirms that at low $\left[\mathrm{CO}_{2}\right]$, active $\mathrm{HCO}_{3}{ }^{-}$transport to the chloroplast is increased at the expense of active $\mathrm{HCO}_{3}{ }^{-}$transport to the coccolith vesicle. A similar competitive

60 reallocation of $\mathrm{HCO}_{3}^{-}$to photosynthesis from calcification at low $\left[\mathrm{CO}_{2}\right]$ has been shown 61 in the laboratory ${ }^{16}$. As a consequence, at low $\left[\mathrm{CO}_{2}\right]$, a smaller proportion of calcification is supported by a direct influx of $\mathrm{HCO}_{3}{ }^{-}$to the coccolith vesicle, decreasing $\varepsilon_{\text {coccolith }}$. This process is amplified in larger cells, which at low $\left[\mathrm{CO}_{2}\right]$ feature the lowest proportion of calcification supported by direct influx of $\mathrm{HCO}_{3}{ }^{-}$to the coccolith vesicle. Consequently, the difference in $\varepsilon_{\text {coccolith }}$ between large and small coccolithophores is greater at low $\left[\mathrm{CO}_{2}\right]$. Culture data and our model indicate that this relationship is non-

67 linear, with the steepest dependence of $\varepsilon_{\text {coccolith }}$ on $\left[\mathrm{CO}_{2}\right]$ over the range $12-19 \mu \mathrm{M}$ (Fig. 1b). Vital effects in $\delta^{18} \mathrm{O}$ have previously been ascribed to changes in the relative contribution of carbonate $\left(\mathrm{CO}_{3}{ }^{2-}\right)$ and $\mathrm{HCO}_{3}{ }^{-}$to coccolith calcite ${ }^{17}$, which produces an effect analogous to that generated by variable relative influx of $\mathrm{CO}_{2}$ and $\mathrm{HCO}_{3}{ }^{-}$to the coccolith vesicle predicted by our $\delta^{13} \mathrm{C}$ model (Supplementary Discussion).

73 Evaluation of $\delta^{18} \mathrm{O}$ and $\delta^{13} \mathrm{C}$ in size-separated coccoliths from five (Integrated) Ocean

74 Drilling Program sites (Supplementary Methods and Supplementary Fig. 9) shows that vital effects of stable isotopes in coccoliths were minimal before and after the Eocene- 
Oligocene (about 34 Myr ago) and Oligocene-Miocene (about 23 Myr ago) transitions, and that large (more than 1\%o) vital effects first appeared during the late Miocene to earliest Pliocene (about 7-5 Myr ago). A striking divergence in isotopic composition in different-sized coccoliths is demonstrated in records from two widely separated sites, Myr ago, only small $\delta^{18} \mathrm{O}$ and $\delta^{13} \mathrm{C}$ differences (less than $0.75 \%$ ) between size fractions are observed. After the divergence, which begins at 6-7 Myr ago at Site 999 and 4-5 Myr ago at Site 1088, persistent vital effects of $1.5-3 \%$ in $\delta^{18} \mathrm{O}$ and $\delta^{13} \mathrm{C}$ are recorded, with large coccoliths consistently recording lighter $\delta^{18} \mathrm{O}$ and $\delta^{13} \mathrm{C}$ relative to smaller coccoliths (Fig. 2). We interpret this diachrony as a real lag that is too large to result from age model discrepancies (Supplementary Methods and Supplementary Fig. 11).

We note that temporal changes in mean coccolith size in the sediments do not affect our data from restricted coccolith size classes.

The marked increase in vital effects in coccoliths in the late Miocene cannot reflect an expansion into a wider range of depth habitats, because the $\delta^{18} \mathrm{O}$ and $\delta^{13} \mathrm{C}$ values in different-sized coccoliths are positively correlated (Fig. 2, Supplementary Fig. 10), not negatively correlated as would be expected from depth segregation in the photic zone ${ }^{13}$. We also find no cause to suggest that the depth habitat of all coccolithophores at both sites migrated from deeper $\mathrm{CO}_{2}$-enriched to shallower $\mathrm{CO}_{2}$-depleted waters within the photic zone (Supplementary Discussion). At Site 999, it is possible that circulation

97 changes associated with the gradual closure of the Central American Seaway about 14 to $3 \mathrm{Myr}$ ago (ref. 18) stemmed the eastward flow of $\mathrm{CO}_{2}$-rich upwelled water from the equatorial Pacific; however, the emergence of the Panama Isthmus is not modelled to strongly affect circulation near Site 1088 (ref. 19). The shift to a large array of vital 
101 effects in coccoliths occurs at a time when there is no evidence for large changes in

102 coccolithophore growth rate at either site, as indicated by coccolith $\mathrm{Sr} / \mathrm{Ca}$ records

103 (Supplementary Methods and Supplementary Fig. 5). A shift from predominantly (more

104 than 70\%) diagenetic calcite to primary coccolith calcite would be required to

105 homogenise a $1.5 \%$ isotopic difference in primary $\delta^{18} \mathrm{O}$ to the less than $0.6 \%$ recorded

106 in older sediments (Supplementary Fig. 8). This is not consistent with the moderate to

107 good coccolith preservation throughout the Miocene-Pliocene at both sites evident in

108 scanning electron microscope images (Supplementary Figs 6 and 7), nor with Sr/Ca

109 values, which confirm biogenic rather than abiogenic (diagenetic) Sr partitioning

110 throughout the Miocene-Pliocene study interval (Supplementary Discussion). The

111 presence of vital effects at the Pliocene end of both records, and their absence at the

112 Miocene end, is unlikely to result from differences in species contributions in a given

113 size fraction over time. Counts of coccoliths in all size fractions from end-member

114 samples show that, despite changes in species composition and size distribution over the

$11516 \mathrm{Myr}$ study interval, the genera or families dominating each size fraction remain

116 similar (Supplementary Table 3). For example, at Site 1088, smallest and largest

117 coccolith size fractions in both Pleistocene and Miocene end-member samples are

118 dominated (more than $70 \% \mathrm{CaCO}_{3}$ ) by small reticulofenestrid and Coccolithus

119 pelagicus coccoliths respectively, yet only the Pleistocene sample records a large array

120 (up to 3\%) of vital effects (Fig. 2).

122 Our model of coccolithophore carbon allocation suggests that the late Miocene

123 emergence of vital effects represents a modification of carbon acquisition strategies of

124 the cells as $\left[\mathrm{CO}_{2}\right]$ decreased below a critical threshold (Fig. 1). We propose that a

125 decrease in $p \mathrm{CO}_{2}$ caused tropical waters (Site 999) to fall below this $\left[\mathrm{CO}_{2}\right]$ threshold at 
126 about $7 \mathrm{Myr}$ ago. Because $\mathrm{CO}_{2}$ is more soluble in cold waters, a continued $p \mathrm{CO}_{2}$ decline

127 into the early Pliocene (about $5 \mathrm{Myr}$ ago) was required before a similar limiting $\left[\mathrm{CO}_{2}\right]$

128 was reached in the cooler sub-Antarctic waters of Site 1088 (Supplementary Fig. 12).

130 The emergence of large-scale vital effects in coccoliths in the late Miocene, rather than

131 at earlier transitions such as the Eocene-Oligocene or Oligocene-Miocene, for which

132 important step decreases in $p \mathrm{CO}_{2}$ are estimated from proxies and inferred from climate

133 records $^{20-23}$, is consistent with culture data ${ }^{12}$, which suggest low sensitivity of $\varepsilon_{\text {coccolith }}$ to

$134\left[\mathrm{CO}_{2}\right]$ variation above $19 \mu \mathrm{M}$. At typical concentrations of dissolved inorganic carbon

135 in the surface ocean $(2050 \mu \mathrm{M})$ and estimated production temperatures for a typical

136 mid-latitude site $\left(20^{\circ} \mathrm{C}\right.$; Supplementary Fig. 5), the range of maximum sensitivity (12-

$\left.13719 \mu \mathrm{M}\left[\mathrm{CO}_{2}\right]\right)$ corresponds to $p \mathrm{CO}_{2}$ in the range 575-375 parts per million by volume

138 (p.p.m.v.). As $\left[\mathrm{CO}_{2}\right]$ decreases below $20 \mu \mathrm{M}$ there is an exponential increase in the

139 requirement for active $\mathrm{HCO}_{3}{ }^{-}$transport to the chloroplast (Supplementary Fig. 4). Since

140 the late Miocene, further decreases in $p \mathrm{CO}_{2}$, even to low values typical of the last

141 glacial ${ }^{13}$, have not resulted in a subsequent increase in the magnitude of size-related

142 vital effects. One explanation could be that further decreases in $\left[\mathrm{CO}_{2}\right]$ were

143 accompanied by a decrease in cellular calcification, thereby limiting further decreases in

144 the supply of $\mathrm{HCO}_{3}{ }^{-}$to the coccolith vesicle relative to calcification. Decreased

145 calcification in coccoliths of a given size over the Cenozoic could support the operation

146 of such a mechanism ${ }^{24,25}$.

147 Few $p \mathrm{CO}_{2}$ proxy reconstructions cover the interval leading up to the divergence of vital

148 effects in coccoliths (12-5 Myr ago). Alkenone-based records suggest low and stable

$149 p \mathrm{CO}_{2}$ during this interval (Fig. 3b). However, these estimates could be too low because

150 of the nature of the applied corrections for temperature and phosphate 
151 concentrations ${ }^{22,26}$. New alkenone-based $p \mathrm{CO}_{2}$ estimates from the western tropical

152 Atlantic covering the mid to late Miocene, although low in resolution, suggest

153 substantially higher values (400-500 p.p.m.v.) ${ }^{27}$. Although uncertainties remain large,

154 stomatal proxies indicate a $p \mathrm{CO}_{2}$ decrease $^{7}$, consistent with inverse modelling of climate

155 data $^{8}$ (Fig. 3b). Our data suggest that substantial surface ocean cooling over the last 15

$156 \mathrm{Myr}$, up to $14{ }^{\circ} \mathrm{C}$ in the subtropics ${ }^{28}$, may reflect an important global $p \mathrm{CO}_{2}$ decrease that

157 is poorly resolved by existing $p \mathrm{CO}_{2}$ proxy records, rather than a decoupling of

158 atmospheric $\mathrm{CO}_{2}$ forcing and climate as suggested by some authors ${ }^{28}$.

160 The appearance of large-scale vital effects in coccoliths between 7 and $5 \mathrm{Myr}$ ago is

161 synchronous with a global expansion in terrestrial $\mathrm{C}_{4}$ plants (that is, those using the $\mathrm{C}_{4}$

162 photosynthetic pathway; mostly tropical grasses) relative to $\mathrm{C}_{3}$ plants (primarily trees)

163 in low-latitudes and mid-latitudes ${ }^{4-6,29}$ (Fig. 3a). In some regions, such as the Himalayan

164 foreland and Arabian Peninsula, it has been suggested that a shift to increasingly arid

165 conditions was the dominant driver of the late Miocene rise in $\mathrm{C}_{4}$ plants ${ }^{29}$. However, the

166 shift to $\mathrm{C}_{4}$ dominance has also been widely interpreted as a response to decreasing

$167 p \mathrm{CO}_{2}$, because at low ratios of atmospheric $\mathrm{CO}_{2}$ to $\mathrm{O}_{2}$ concentrations $\mathrm{C}_{4}$ plants have a

168 competitive advantage over $\mathrm{C}_{3}$ plants ${ }^{4-6}$. The presence of a biochemical carbon-

169 concentrating mechanism allows $\mathrm{C}_{4}$ plants to decrease energetically costly

170 photorespiration rates, and also to decrease stomatal conductance (a measure of the rate

171 at which water and $\mathrm{CO}_{2}$ can diffuse in or out of the leaf), thus decreasing water loss.

172 Conditions that favour $\mathrm{C}_{4}$ over $\mathrm{C}_{3}$ plants are suggested to occur below a $p \mathrm{CO}_{2}$ of about

173500 p.p.m.v. when accompanied by high temperatures during the growing season (that

174 is, at low latitudes), or at lower $p \mathrm{CO}_{2}$ in cooler climates ${ }^{4,5}$. Thus, both terrestrial and

175 marine photosynthesizers may be showing adaptation at a common $p \mathrm{CO}_{2}$ threshold. 
177 We show that the large array of isotopic fractionations in modern coccolith carbonate is

178 indicative of the operation of strong carbon-concentrating mechanisms in

179 coccolithophore cells, which became highly significant since the latest Miocene. We

180 speculate that this change occurred as a threshold response to increased $\mathrm{CO}_{2}$ limitation,

181 beginning in the late Miocene in the tropical oceans and progressing to higher latitudes

182 by the earliest Pliocene. This increase in the degree of active carbon uptake by

183 coccolithophores will need to be accounted for in the application of $\varepsilon_{\mathrm{p}}$ to estimates of

$184\left[\mathrm{CO}_{2}\right]$ (ref. 30). The relatively low $\left[\mathrm{CO}_{2}\right]$ threshold suggested to have driven the late

185 Miocene diversification of coccolithophore carbon acquisition strategies is consistent

186 with estimates of less than 500 p.p.m.v. $p \mathrm{CO}_{2}$ required to promote the tropical $\mathrm{C}_{4^{-}}$

187 dominated ecosystems that also expanded over this interval ${ }^{4-6}$. We speculate that such a

188 low $p \mathrm{CO}_{2}$ threshold, affecting both marine and terrestrial primary producers, could be

189 reversed within decades as a result of rapid anthropogenic $\mathrm{CO}_{2}$ release and absorption

190 by the ocean.

191

192 Methods summary

193 We adapt a model for the $\delta^{13} \mathrm{C}$ composition of photosynthetically fixed carbon in

194 diatoms ${ }^{31}$ with an additional module for the coccolith vesicle, allowing us to simulate

195 the $\delta^{13} \mathrm{C}$ of coccolith calcite as a function of the passive and active carbon fluxes into

196 the coccolith vesicle and cell (model ACTI-CO; see Supplementary Discussion).

197 Coccolith size fractions were separated from bulk IODP sediment samples using site-

198 specific and interval-specific settling and microfiltration protocols (Supplementary

199 Methods). Coccolith $\delta^{18} \mathrm{O}$ and $\delta^{13} \mathrm{C}$ were measured on a $\mathrm{Nu}$ Perspective dual-inlet

200 isotope ratio mass spectrometer connected to a NuCarb carbonate preparation system, 
201 with an analytical precision of $0.06 \%$ for $\delta^{18} \mathrm{O}$ and $0.05 \%$ for $\delta^{13} \mathrm{C}(1 \sigma)$, at Oviedo

202 University. Mean reproducibility, based on duplicate analyses of splits of 21 random

203 samples from Sites 999 and 1088, is $0.08 \%$ for $\delta^{18} \mathrm{O}$ and $0.06 \%$ for $\delta^{13} \mathrm{C}(1 \sigma)$. Sr/Ca

204 was determined in two coccolith size fractions at both Sites 999 and 1088. Reducing

205 and ion-exchange treatments were first applied to clean the samples, followed by gentle

206 dissolution in acetic acid with an ammonium acetate buffer for $12 \mathrm{~h}$. Calcium content

207 was measured on a split of all samples, which were then diluted to constant calcium

208 concentrations for $\mathrm{Sr} / \mathrm{Ca}$ analysis by inductively coupled plasma optical emission

209 spectroscopy on a Thermo ICAP DUO 6300 at Oviedo University. Sr/Ca data were

210 corrected for site-specific variations in sea surface temperature (Supplementary

211 Methods). All coccolith counts were performed on standard smear slides with a light

212 microscope under cross-polarized light at x1250 magnification. To assess preservation,

213 coccolith samples on polycarbonate filters were mounted onto a stub, coated with gold

214 and imaged on a JEOL 6610LV scanning electron microscope.

\section{References}

2171 Tortell, P. D. Evolutionary and Ecological Perspectives on carbon acquisition in $218 \quad$ phytoplankton. Limnology and Oceanography 45, 744-750 (2000).

2192 Raven, J. A., Giordano, M., Beardall, J. \& Maberly, S. C. Algal and aquatic plant carbon concentrating mechanisms in relation to environmental change. Photosynthesis Research 109 (2011).

2223 Reinfelder, J. R. Carbon Concentrating Mechanisms in Eukaryotic Marine 
2244 Cerling, T. E. et al. Global vegetation change through the Miocene-Pliocene 225 boundary. Nature 389, 153-158 (1997).

2265 Ehleringer, J. R., Cerling, T. E. \& Helliker, B. R. C 4 photosynthesis, 227 atmospheric $\mathrm{CO}_{2}$, and climate. Oecologia 112, 285-299 (1997).

2286 Zhang, C. et al. $\mathrm{C}_{4}$ expansion in central Inner Mongolia during the latest 229 Miocene and early Pliocene. Earth and Planetary Science Letters 287, 311-319 $230 \quad$ (2009).

2317 Beerling, D. J. \& Royer, D. L. Convergent Cenozoic $\mathrm{CO}_{2}$ history. Nature $232 \quad$ Geoscience 4, 418-420 (2011).

2338 van de Wal, R. S., de Boer, B., Lourens, L. J., Köhler, P. \& Bintanja, R. 234 Reconstruction of a continuous high-resolution $\mathrm{CO}_{2}$ record over the past 20 235 million years. Climate of the Past 7, 1459-1469 (2011).

2369 Zachos, J. C., Dickens, G. R. \& Zeebe, R. E. An early Cenozoic perspective on 237 greenhouse warming and carbon-cycle dynamics. Nature 451, 279-283 (2008).

$23810 \quad$ Dudley, W. C., Blackwelder, P., Brand, L. \& Duplessy, J. C. Stable isotopic 239 composition of coccoliths. Marine Micropaleontology 10, 1-8 (1986).

24011 Ziveri, P. et al. Stable isotope "vital effects" in coccolith. Earth and Planetary $241 \quad$ Science Letters 210, 137-149 (2003).

24212 Rickaby, R. E. M., Henderiks, J. \& Young, J. N. Perturbing phytoplankton: 243 response and isotopic fractionation with changing carbonate chemistry in two 244 coccolithophore species. Climate of the Past 6, 771-785 (2010). 
24513 Bolton, C. T., Stoll, H. M. \& Mendez Vicente, A. Vital effects in coccolith 246 calcite: Cenozoic climate- $p \mathrm{CO}_{2}$ drove the diversity of carbon acquisition strategies in coccolithophores? Paleoceanography 27 (2012).

24814 Stoll, H. M. Limited range of interspecific vital effects in coccolith stable 249 isotopic records during the Paleocene-Eocene thermal maximum.

$250 \quad$ Paleoceanography 20, PA1007 (2005).

25115 Rost, B., Zondervan, I. \& Riebesell, U. Ligh-dependent carbon isotope 252 fractionation in the coccolithophorid Emiliania huxleyi. Limnology and $253 \quad$ Oceanography 47, 120-128 (2002).

25416 Bach, L. T. et al. Dissecting the impact of $\mathrm{CO}_{2}$ and $\mathrm{pH}$ on the mechanisms of 255 photosynthesis and calcification in the coccolithophore Emiliania huxleyi. New 256 Phytologist 199, 121-134. doi: 10.1111/nph.12225 (2013).

25717 Ziveri, P., Thoms, S., Probert, I., Geisen, M. \& Langer, G. A universal carbonate 258 ion effect on stable isotope ratios in unicellular planktonic calcifying organisms. Biogeosciences 9, 1025-1032 (2012).

26018 Kameo, K. \& Sato, T. Biogeography of Neogene calcareous nannofossils in the 261 Caribbean and the eastern equatorial Pacific- floral response to the emergence of 262 the Isthmus of Panama. Marine Micropaleontology 39, 201-218 (2000).

26319 Schneider, B. \& Schmittner, A. Simulating the impact of the Panamanian 264 seaway closure on ocean circulation, marine productivity and nutrient cycling. Earth and Planetary Science Letters 246, 367-380 (2006).

26620 Kürschner, W. M., Kvacek, Z. \& Dilcher, D. L. The impact of Miocene 
terrestrial ecosystems. Proceedings of the National Academy of Sciences USA 105, 449-453 (2008).

21 Pagani, M., Arthur, M. A. \& Freeman, K. H. Miocene evolution of atmospheric carbon dioxide. Paleoceanography 14, 273-292 (1999).

22 Pagani, M. et al. The role of carbon dioxide during the onset of Antarctic glaciation. Science 334, 1261-1264 (2011).

23 Pearson, P. N., Foster, G. L. \& Wade, B. S. Atmospheric carbon dioxide through the Eocene-Oligocene climate transition. Nature 461 (2009).

24 Preiss-Daimler, I., Baumann, K.-H. \& Heinrich, R. Carbonate budget mass estimates for Neogene discoasters from the Equatorial Atlantic (Ceara Rise: ODP Site 927). Journal of Micropaleontology 31, 169-178 (2012).

25 Stoll, H. M. et al. Insights on coccolith chemistry from a new ion probe method for analysis of individually picked coccoliths. Geochemistry Geophysics Geosystems 8, doi:doi:10.1029/2006GC001546 (2007).

28226 Pagani, M., Liu, Z., LaRiviere, J. \& Ravelo, A. C. High Earth-system climate 283 sensitivity determined from Pliocene carbon dioxide concentrations. Nature $284 \quad$ Geoscience 3, 27 - 30 (2009).

28527 Zhang, Y. G., Pagani, M., Liu, Z., Bohaty, S. M. \& DeConto, R. A 40 million286 year history of atmospheric $\mathrm{CO}_{2}$. Philisophical Transactions of the Royal 287 Society A (In press).

28828 LaRiviere, J. P. et al. Late Miocene decoupling of oceanic warmth and atmospheric carbon dioxide forcing. Nature 486, 97-100 (2012). 
29 Huang, Y., Clemens, S. C., Liu, W., Wang, Y. \& Prell, W. L. Large-scale hydrological change drove the late Miocene $\mathrm{C}_{4}$ plant expansion in the Himalayan foreland and Arabian Peninsula. Geology 35, 531-534, doi: 10.1130/G23666A (2007).

30 Laws, E. A., Popp, B. N., Cassar, N. \& Tanimoto, J. 13C discrimination patterns in oceanic phytoplankton: likely influence of $\mathrm{CO}_{2}$ concentrating mechanisms, and implications for palaeoreconstructions. Functional Plant Biology 29, 323$333(2002)$.

31 Hopkinson, B. M., Dupont, C. L., Allen, A. E. \& Morel, F. M. M. Efficiency of the $\mathrm{CO}_{2}$-concentrating mechanism of diatoms. Proceedings of the National Academy of Sciences USA 108, 3830-3837 (2011).

Supplementary Information is linked to the online version of the paper at www.nature.com/nature.

Acknowledgements We thank L. Abrevaya and A. Mendez for laboratory assistance and K. Lawrence for access to unpublished data. This work used samples provided by the (Integrated) Ocean Drilling Program (IODP). The IODP is sponsored by the U.S. National Science Foundation and participating countries under management of the IODP Management International, Inc (IODP-MI). Funding for this research was provided by European Research Council grant UE-09-ERC-2009-STG-240222-PACE (H.M.S.) and a DuPont Young Professor Award to H.M.S. 
313 Author Contributions C.T.B. and H.M.S. designed the study and wrote the paper.

314 C.T.B. separated coccoliths and performed stable isotope, light microscope and

315 scanning electron microscope analyses. H.M.S. designed and ran the model.

317 Author Information Reprints and permissions information is available at

318 www.nature.com/reprints. The authors declare no competing financial interests. Readers

319 are welcome to comment on the online version of this article at www.nature.com/nature.

320 Correspondence and requests for materials should be addressed to C.T.B.

321 (cbolton@geol.uniovi.es).

Figure captions

Figure 1: $\mathrm{HCO}_{3}{ }^{-}$allocation to the chloroplast and coccolith vesicle inferred from

$\boldsymbol{\varepsilon}_{\text {coccolith }}$ measured in culture. a, simplified modelled coccolithophore carbon fluxes

(details in Supplementary Fig. 1). CV, coccolith vesicle, CHL, chloroplast. Dashed

black arrows represent passive fluxes, and solid black arrows represent active fluxes. b, $\mathrm{HCO}_{3}{ }^{-}$influx relative to chloroplast $\mathrm{HCO}_{3}{ }^{-}$influx, e, Chloroplast $\mathrm{HCO}_{3}{ }^{-}$influx relative to diffusive $\mathrm{CO}_{2}$ uptake by cell. Data in c-e are inferred from inverse model

332 (Supplementary Information) using default parameters (Supplementary Table 1).

333 Symbols in b-e: diamonds, Gephyrocapsa oceanica; squares, Coccolithus pelagicus

334 subsp. braarudii. Blue shading indicates the range of steepest dependence of $\varepsilon_{\text {coccolith }}$ on $335\left[\mathrm{CO}_{2}\right]$. 
337 Figure 2: Divergence of vital effects in coccoliths. a, Benthic foraminiferal $\delta^{18} \mathrm{O}$ (ref.

338 9) (data points in light grey, smoothed with seven-point running mean) and $\delta^{13} \mathrm{C}$ of

339 smallest and largest coccoliths (coloured circles). All $\delta^{18} \mathrm{O}$ and $\delta^{13} \mathrm{C}$ values are

340 measured against Vienna Pee Dee Belemnite (VPDB). See Supplementary Fig. 10 for

341 complete size fraction data. Bubble size scales with approximate coccolith size. For the

342 Neogene, mean values for 3-Myr time windows are shown from Sites 999 and 1088.

343 The grey box denotes the time interval in b-e (16-0 Myr ago). b, c, $\delta^{18} \mathrm{O}(\mathbf{b})$ and $\delta^{13} \mathrm{C}(\mathbf{c})$

344 of different-sized coccoliths from Site 999. d, e, $\delta^{18} \mathrm{O}(\mathbf{d})$ and $\delta^{13} \mathrm{C}(\mathbf{e})$ of different-sized

345 coccoliths from Site 1088. To remove secular trends and highlight differences between

346 size fractions, all coccolith isotopes are normalized to the smallest coccolith size

347 fraction in each sample. Note the different scales of $\delta^{18} \mathrm{O}$ and $\delta^{13} \mathrm{C}$ axes.

Figure 3: Evolution of vital effects in coccoliths, $\mathrm{C}_{4}$ photosynthesis, and $p \mathrm{CO}_{2}$ since

$35016 \mathrm{Myr}$ ago. a, $\delta^{13} \mathrm{C}$ difference between smallest and largest coccolith size fractions at

351 Sites 999 (red) and 1088 (orange) and the range of tooth enamel $\delta^{13} \mathrm{C}$ values (blue shading; data from ref. 4; only North American data $<37^{\circ}$ plotted; however other regions show a similar pattern). The propagated analytical uncertainty on coccolith $\delta^{13} \mathrm{C}$ differences is $0.07 \%$. $\mathbf{b}$, Estimates of $p \mathrm{CO}_{2}$ from various proxies: foraminifer boron isotopes (blue and yellow horizontal crosses), stomata (red diagonal crosses), alkenone $\delta^{13} \mathrm{C}$ maximum and minimum estimates (pink, green, grey and orange shading), and inverse modelling of deep-sea $\delta^{18} \mathrm{O}$ (black line). Note the change in scale at 500 p.p.m.v. Vertical error bars represent the uncertainty reported in published $p \mathrm{CO}_{2}$ estimates. See Supplementary Information for $p \mathrm{CO}_{2}$ data references and details of uncertainty derivation for each reference. 
$\diamond \diamond$ G. oceanica (small cell) $\square \square$ C. braarudii (large cell)

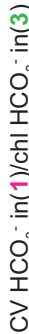

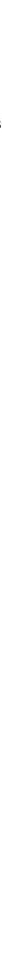

㽞

$\square \square$

$\diamond$

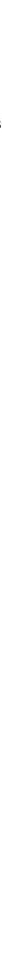

CYTOSOL 
